\title{
Effect of Bacteriocin (ALC102) of Enterococcus faecium GRD AA on Biofilm Forming Listeria monocytogenes MTCC 657
}

\author{
Arya Radhakrishnan Krishna $\mathbb{D}^{\mathrm{D}}$, Swathy Krishna Jayalekshmi ${ }^{(D)}$, \\ Trisha Mary Pandipilly Antony (D) and Suganthi Ramasamy* (D) \\ School of Biotechnology, Dr. G.R.Damodaran College of Science (Autonomous), \\ Coimbatore - 641 014, Tamil Nadu, India.
}

\begin{abstract}
Antilisterial bacteriocin producing strain were isolated from milk samples and were subjected to $16 \mathrm{~S}$ rRNA sequencing and found to be of genus Enterococcus faecium. The bacteriocin ALC102 were partially purified by Amberlite XAD-16 adsorption followed by column chromatography. The biofilm formation capacity of Listeria monocytogenes MTCC 657 were evaluated by tube method and CV binding assay. Biofilm formation on different abiotic substrates were also evaluated. Among three substrates stainless steel had a strong biofilm formation followed by glass and aluminum foil. From the results of biofilm eradication studies, the bacteriocin ALC102 showed almost similar activity of commercial bacteriocin nisin on all the substrates at $45^{\circ} \mathrm{C}, 30^{\circ} \mathrm{C}, 4^{\circ} \mathrm{C}$ and $-20^{\circ} \mathrm{C}$. Based on $\mathrm{CBD}^{\otimes}$ biofilm eradication assay, the eradication potential of ALC102 and nisin were found to be similar on high $\left(45^{\circ} \mathrm{C}\right)$ and freezing $\left(-20^{\circ} \mathrm{C}\right)$ temperatures. From the study, antilisterial bacteriocin ALC102 found to be able to inhibit the biofilm formed Listeria monocytogenes MTCC 657 at different temperatures and different incubation periods (24h, $48 \mathrm{~h}$ and $72 \mathrm{~h})$. The biofilm eradication potential of antilisterial bacteriocin ALC102 was similar to nisin. Neither incubation temperature nor incubation period doesn't altered the activity of the bacteriocin. So this bacteriocin can be considered as a potential competitor in food industry and we strongly recommend the use of this bacteriocin from Enterococcus faecium GRD AA in the food preservation industry to a higher temperature $\left(45^{\circ} \mathrm{C}\right)$ to freezing temperature $\left(-20^{\circ} \mathrm{C}\right)$.
\end{abstract}

Keywords: Enterococcus faecium, Bacteriocin, Listeria monocytogenes, Biofilm, Nisin

*Correspondence: sugantham2000@gmail.com; +91 9843134681

(Received: August 20, 2021; accepted: January 14, 2022)

Citation: Krishna AR, Jayalekshmi SK, Antony TMP, Ramasamy S. Effect of Bacteriocin (ALC102) of Enterococcus faecium GRD AA on Biofilm Forming Listeria monocytogenes MTCC 657. J Pure Appl Microbiol. 2022;16(1):481-493. doi: 10.22207/JPAM.16.1.46

(C) The Author(s) 2022. Open Access. This article is distributed under the terms of the Creative Commons Attribution 4.0 International License which permits unrestricted use, sharing, distribution, and reproduction in any medium, provided you give appropriate credit to the original author(s) and the source, provide a link to the Creative Commons license, and indicate if changes were made. 


\section{INTRODUCTION}

Biofilms formed by microorganisms are often explained as immobile microbial consortia fixed in a three dimensional structure which consists of multicellular groups of prokaryotic and/or eukaryotic cells lodged in a matrix composed of not less than of matter incorporated by the microbial group. ${ }^{1}$ Formation of biofilm is a multistep procedure that begins with fastening of microbes followed by production and collection of extra cellular matrix composed more than one polymeric substance like proteins, polysaccharides, humic substances, extracellular DNA and occasionally other molecules which are involved in cell to cell signaling. ${ }^{2}$ Bill Costerton and coworkers presented the first description of biofilms to the public in 1978, and bioscience technology has been a significant topic of study since then. Nowadays, studies reported that biofilm is a well-established by the majority of the microorganisms in the environment exists as adhered to the surfaces as biofilm ecosphere as not as hovering microrganisms. ${ }^{3}$

Listeria monocytogenes is a Gram positive foodborne pathogen, which was first reported in 1926 in the course of an outbreak that affected rabbits and guinea pigs. ${ }^{4}$ It was accepted as an etiological agent of human infections in the 1970 s and recognized in $1980 s^{5}$ as a foodborne pathogen. Whereas, the total of contagions per annum is comparatively low (round about 23,150 cases were estimated globally in 2010), the death rate infected individuals is higher (20\%-30\%). ${ }^{6}$ Most adults get mild to severe gastroenteritis after eating Listeria monocytogenes contaminated food; however, children, the elderly, immunocompromised persons, and pregnant women are more susceptible, a little amount of food contamination leads to bacterial infections, ensuing bacterial meningitis or infections to the fetus resulting in miscarriage or difficulties in pregnancy. ${ }^{7}$ Listeria monocytogenes is psychotropic, capable to multiply in temperature less than $0^{\circ} \mathrm{C}$. The bacteria are able to grow in $\mathrm{pH}$ range of 4.6 and 9.5 and has a low water activity of $0.92 .{ }^{8}$ Listeria discovers beneficial growth conditions on grounds, sewers and equipment in the food processing industry and environments preferably in the freezing and moist atmosphere of deep freeze rooms where non-psychotropic microbes commonly get through. ${ }^{9,10}$

Listeria monocytogenes strains are usually found on the environments of food industries and food processing, notable in cold and freeze premises, through these are regularly flushed and sanitized. ${ }^{11}$ The bacteria might enter in the food processing environments via several ways and it gets established. ${ }^{12}$ In the case of Listeria monocytogenes these activities are assisted by different factors like its ability to grow in different conditions like broad $\mathrm{pH}$ range, salt tolerance, growth at freezing temperature, resistance to various stress conditions and biofilm forming capacity. The potential of Listeria monocytogenes to endure for long period of time in food processing equipment and environments of food industries, under unfavorable conditions, and are connected to biofilm formation, and this conspires the scientific community. Listeria monocytogenes is capable to attach to a wide range of food contact surfaces, including polystyrene, polypropylene, glass, stainless steel, quartz, marble and wood..$^{13}$ Listeria monocytogenes biofilms are protected by numerous environmental factors like UV-rays, noxious materials, acids, evaporation, saltiness and antimicrobial compounds and it overcomes greater concentrations of disinfectants and sanitizers hindering the disinfection of the surfaces. ${ }^{10,14,15}$

Different methods have been taken to put a stop to control the biofilm formation on various food contact surfaces and also in medical apparatus. The prevention of Listeria monocytogenes biofilms in food processing industries is done mainly by cleaning and disinfection of apparatus, with certain compounds like acetic acid, lactic acid, sodium hypochlorite, quaternary ammonium and hydrogen peroxide. ${ }^{16}$ The usage of antimicrobial peptides (bacteriocins) or bacteriocin producing bacteria also help to prevent the primary attachment and biofilm formation by Listeria monocytogenes on different substrates. ${ }^{17}$ Bacteriocins can also be used to increase consumer defence against foodborne bacteria. Bacteriocin producing cultures can be implied directly into food as purified forms, like nisin produced by Lactococcus lactis which is a commercial food preservative permitted in various countries. Likewise, certain natural compounds 
like essential oils and culinary plant extracts, can be used to control biofilm formation by Listeria monocytogenes on food processing environments and surfaces.$^{18}$ Although, little is known about potential inhibitors of cell to cell signaling in Listeria monocytogenes biofilm, which can be a crucial way for new researches. ${ }^{15}$

Among lactic acid bacteria, enterococci are common occupants of animal and human gastrointestinal tract and also present in meat, vegetables and cheeses and cheese products. ${ }^{19} \mathrm{In}$ addition to its technical features, enterococci are capable of creating bacteriocins called enterocins, which are typically found in high concentrations in a variety of cheeses. ${ }^{20}$ These bacteriocins forms spores inside the cytoplasmic membrane of the cells in the bacteria, there by exhausting the transmembrane capability and or the $\mathrm{pH}$ gradient which results in the cell apoptosis. ${ }^{21}$ Various enterococci strains have been applied in falsely contaminated dairy foods like milk, soft cheese and soy milk to prevent the growth of foodborne pathogens like Listeria monocytogenes and Staphylococcus aureus without altering the activity of the starter culture or the organoleptic nature of the product. ${ }^{22}$ The aim of the study was to isolate antilisterial bacteriocin producing strain from milk sample and to purify the antilisterial bacteriocin from it. A parallel study were conducted to find out the biofilm forming ability of Listeria monocytogenes MTCC 657 by different methods using different abiotic substrates. And also to find out the biofilm eradication potential of the isolated antilisterial bacteriocin on Listeria monocytogenes MTCC 657 biofilms by MTP method and CBD ${ }^{\circledR}$ method.

\section{MATERIALS AND METHODS}

\section{Screening of bacteriocin producing bacteria}

Milk samples were collected from milk vendors from Coimbatore district of Tamil Nadu, India. The sample were diluted serially (up to tenfold) and plated in deMan, Rogosa, and Sharpe (MRS) agar (HiMedia) using spread plate technique and incubated for $24-72 \mathrm{~h}$ at $30^{\circ} \mathrm{C}-37^{\circ} \mathrm{C}$. The bacteriocin production ability of the strain were identified using spot-on-lawn (SOL) method against test organism Listeria monocytogenes (MTCC 657). The lyophilized form of test organism Listeria monocytogenes MTCC 657 were purchased from microbial type culture collection (MTCC). All the isolates were maintained in MRS agar and Nutrient agar (HiMedia, India) respectively. The isolate were identified based on biochemical and phenotypical (16S rRNA sequencing) characteristics. For phylogenetic identification, the bacterial DNA was amplified with $27 \mathrm{~F}$ and $1492 \mathrm{R}$ primers ${ }^{23}$ and then sent to Eurofins Scientific, Bangalore (India). The gene sequence was obtained and submitted to GenBank (NCBI).

\section{Bacteriocin production and purification}

The crude extract of the bacteriocin from the strain were harvested from production medium (TGE+Tween 80). It was then purified using partially by Amberlite XAD-16 (HiMedia, India) resin adsorption by column chromatography. Five grams of Amberlite XAD-16 resin were soaked in $50 \%$ isopropanol overnight at $4^{\circ} \mathrm{C}$. This was then washed with distilled water repeatedly to remove isopropanol. The Amberlite XAD-16 was then added to $250 \mathrm{~mL}$ of heat stabilized cell free supernatant and incubated at room temperature in a shaking incubator for $4 \mathrm{~h}$. After incubation this was then transferred to chromatographic column packed with Amberlite resins for elution. First the matrix was washed with $20 \mathrm{~mL}$ of deionized water and then with $20 \mathrm{~mL}$ of $40 \%$ ethanol. The extract was then eluted with $20 \mathrm{~mL}$ of $70 \%$ isopropanol followed by washing with $100 \%$ ethanol. The eluted crude extract was evaporated to half its volume called as Amberlite fraction and stored for further analysis at $4^{\circ} \mathrm{C}$.

Nisin

$100 \mathrm{mG}$ of nisin (HiMedia, India) was solubilized in $10 \mathrm{~mL}$ of $0.02 \mathrm{~N} \mathrm{HCl}$ to give a concentration of $101 \mathrm{IU} / \mathrm{mL}(40 \mathrm{IU}=1 \mathrm{G})$. The solution was then filter sterilized using $0.45 \mathrm{~mm}$ filters and stored at $-4^{\circ} \mathrm{C} .^{24}$

\section{Biofilm formation studies}

The objective of this study was to find out the biofilm forming capacity of Listeria monocytogenes MTCC 657 on various abiotic substrates such as stainless steel, glass and aluminum foil at different temperature conditions and in order to evaluate the biofilm eradication potential of nisin and antilisterial bacteriocin ALC102. A parallel study was carried out to determine minimum inhibitory concentration (MIC) and minimum biofilm eradication concentration 
(MBEC) of ALC102 and nisin (standard) against Listeria monocytogenes MTCC657 using Calgary Biofilm Device ${ }^{\circledR}\left(\mathrm{CBD}^{\circledR}\right)$.

\section{Tube method}

Listeria monocytogenes MTCC 657 strain was tested for biofilm formation by the method according to. ${ }^{25} \mathrm{~A}$ loopful of overnight culture were inoculated to $5 \mathrm{~mL}$ of tryptic soy broth (TSB, HiMedia, India) test tubes and kept for incubation at $37^{\circ} \mathrm{C}$ for $72 \mathrm{~h}$. The contents were discarded after incubation and washed with phosphate buffered saline (PBS) pH-7.3 and dried at room temperature. The test tubes were then stained with $4 \%$ crystal violet (CV) solution and rotated uniformly and the contents were discarded. The tubes were kept upside down and drained. The positive formation of biofilm were observed as a visible film in the sides and bottom of the test tubes. ${ }^{26}$

\section{Microtiter plate (MTP) method}

Listeria monocytogenes MTCC 657 culture were inoculated from overnight cultured plates into $5 \mathrm{~mL}$ of TSB broth and kept for incubation at $30^{\circ} \mathrm{C}$ for $18 \mathrm{~h}$. Following incubation, it was then transferred $(125 \mu \mathrm{L})$ to $5 \mathrm{~mL}$ of TSB medium again. The culture was then vortexed for $1 \mathrm{~min}$ and volume of $100 \mu \mathrm{L}$ were transferred into wells of a 96 well microtiter plate. The plate were covered tightly with a lid ad kept for incubation for $24 \mathrm{~h}, 48 \mathrm{~h}$ and $72 \mathrm{~h}$ at $30^{\circ} \mathrm{C}$. For each plate, 12 wells comprising of $100 \mu \mathrm{L}$ growth medium without microorganism served as control. After each incubation, the cultures were decanted and cell densities were measured spectrophotometrically at $595 \mathrm{~nm}$. The plates were then washed three times with deionized water to eliminate loosely bounded bacteria and air dried for $3 \mathrm{~min}$ at $30^{\circ} \mathrm{C} .100 \mu \mathrm{L}$ of $95 \%$ ethyl alcohol were added to each well for destaining the biofilm and the concentration of CV were determined by measuring optical density at 595nm (OD595).

\section{Biofilm formation on different substrates}

The biofilm forming ability of Listeria monocytogenes MTCC 657 was tested on different abiotic surfaces. In this study, common substrates in food industries were selected (glass, aluminum foil and stainless steel). Overnight culture of Listeria monocytogenes MTCC 657 were grown in $100 \mathrm{~mL}$ conical flask containing TSB and incubated for $24 \mathrm{~h}$ at $30^{\circ} \mathrm{C}$. The abiotic surfaces glass, aluminum foil and stainless steel were cleaned using detergent and distilled water and dried in hot air oven for $30 \mathrm{~min}$ at $75^{\circ} \mathrm{C}$. After $24 \mathrm{~h}$ incubation, sterile substrates were carefully added to the conical flasks and incubated for $24 \mathrm{~h}, 48 \mathrm{~h}$ and $72 \mathrm{~h}$ at $30^{\circ} \mathrm{C}$. Each set of substrates were removed aseptically for biofilm quantification after each incubation period method for crystal violet (CV) binding assay. ${ }^{27}$ The substrates were washed with $5 \mathrm{~mL}$ of deionized water and the leftover adherent bacteria were fixed with $250 \mathrm{~mL}$ of methanol. The substrate were stained with $4 \%$ of CV for $15 \mathrm{~min}$ and the excess stain were removed in flowing tap water and air dried. The dye bound to the adherent cells were resolubilized with $25 \%$ of $33 \%$ glacial acetic acid. The resolubilized liquid was collected for each substrate and absorbance were measured at $595 \mathrm{~nm}$ using spectrophotometer (HACH). The control (medium only) without test organism served as blank. ${ }^{28}$

Biofilm eradication studies on Listeria monocytogenes MTCC 657 using different bacteriocins

\section{Microtiter plate method}

For biofilm eradication studies, microtiter plate method was slightly modified in which the abiotic substrates glass, aluminum foil and stainless steel were added to every wells of 96 well microtiter plate and filled with $200 \mu \mathrm{L}$ of bacterial suspension. The broth without bacterial culture served as control. The plates were closed with lid and kept for incubation for $24 \mathrm{~h}, 48 \mathrm{~h}$ and $72 \mathrm{~h}$ at various temperatures of $45^{\circ} \mathrm{C}, 30^{\circ} \mathrm{C}, 4^{\circ} \mathrm{C}$ and $-20^{\circ} \mathrm{C}$. After each incubation period, the substrates were removed and transferred into sterile and fresh microtiter plate and washed with $250 \mu \mathrm{L}$ of PBS for three times. The plates were shaken vigorously to remove non adherent bacteria and contents were decanted. Added $200 \mu \mathrm{L}$ different concentrations of Nisin and ALC102 except in control wells and incubated for $1 \mathrm{~h}$. After incubation, the bacteriocins were removed and washed with sterile distilled water for five times to remove loosely adherent bacteria, Nisin and ALC102. ${ }^{24}$ The substrates was then stained with $200 \mu \mathrm{L}$ of $2 \%$ crystal violet for $5 \mathrm{~min}$. Excess stain was washed off and air dried. The dye bound to the attached cells were resolubilized with $160 \mu \mathrm{L}$ of $33 \%$ glacial acetic acid and incubated for $15 \mathrm{~min}$ at $30^{\circ} \mathrm{C}$. The $O D$ were measured at $595 \mathrm{~nm}$ using ELISA reader. The 
reduction percentage was calculated using the following formula:

Reduction potential $=\frac{\text { Control } \mathrm{OD}_{595 \mathrm{~nm}}-\mathrm{Test}_{\mathrm{OD}} \mathrm{D}_{595 \mathrm{~nm}}}{{\text { Control } O D_{595 \mathrm{~nm}}}} \times 100$

Calgary Biofilm Device ${ }^{\circledR}$ Method $\left(\right.$ CBD $\left.^{\circledR}\right)$

The biofilm of Listeria monocytogenes

MTCC 657 were grown at different temperatures $\left(45^{\circ} \mathrm{C}, 30^{\circ} \mathrm{C}, 4^{\circ} \mathrm{C}\right.$ and $\left.-20^{\circ} \mathrm{C}\right)$ on $\mathrm{CBD}^{\circledR}$ to evaluate biofilm eradication potential of Nisin and antilisterial bacteriocin ALC102 at different concentrations by calculating MIC and MBEC values. The procedure follows:

Day 1

Growing Listeria monocytogenes MTCC 657 biofilm: Listeria monocytogenes MTCC 657 inoculum were prepared and $200 \mu \mathrm{L}$ each culture were added to all wells in a 96-well microtiter plate closed with lid containing polystyrene pegs and incubated for $72 \mathrm{~h}$ at $45^{\circ} \mathrm{C}, 30^{\circ} \mathrm{C}, 4^{\circ} \mathrm{C}$ and $-20^{\circ} \mathrm{C}$.

Day 2

Preparation of Challenge plate: After $72 \mathrm{~h}$ incubation, a fresh and sterile microtiter plate was taken and two fold dilutions of Nisin and antilisterial bacteriocin ALC102 were prepared in TSB and added $(200 \mu \mathrm{L})$ to the wells. Biofilm formed pegs were washed with sterile PBS for three times. After washing, the pegs were immersed into the fresh microtiter plate containing bacteriocins and incubated at $45^{\circ} \mathrm{C}, 30^{\circ} \mathrm{C}, 4^{\circ} \mathrm{C}$ and $-20^{\circ} \mathrm{C}$ for $24 \mathrm{~h}$.

Day 3

Neutralization and recovery: To a fresh microtiter plate, $200 \mu \mathrm{L}$ of freshly prepared TSB were added to all the wells. The pegs from the challenge plate were removed and rinsed twice with PBS. The pegs were then immersed in a fresh microtiter plate (recovery plate) and sonicated for $24 \mathrm{~h}$ to disrupt biofilm from the pegs. After incubation the contents were decanted and to this $200 \mu \mathrm{L}$ of neutralizing agent (Proteinase $\mathrm{K})$ were added and kept for $24 \mathrm{~h}$ incubation. To determine the MIC values, the turbidity in the wells of challenge plate was read at $650 \mathrm{~nm}$ using ELISA reader. The MIC $\left(\mathrm{OD}_{650}<0.1\right)$ is described as the minimum concentration of bacteriocin which prevents the growth of the microorganism. To determine the MBEC values, the turbidity in the wells of recovery plate was read at $650 \mathrm{~nm} .{ }^{29,30}$ Statistical Analysis

All the experiments in the study was performed in triplicates and results were indicated as Mean \pm SD. A one way analysis of variance (ANOVA) was used to find out significant difference between mean of each surface and strain. Statistical significance were studied at $P<0.05$. Graphs were framed using GraphPad Prism 8.0

\section{RESULTS AND DISCUSSION \\ Screening of bacteriocin of bacteriocin producing bacteria}

Milk was selected as source of isolating bacteriocin producing bacteria. From more than 15 colonies screened for the antibacterial activity against Listeria monocytogenes MTCC 657, one colony found to produce zone of inhibition and named as GRD S1. The pure culture was maintained in MRS agar. The isolated strain were found to be Gram positive cocci, catalase negative and vancomycin resistant. The strain was subjected to $16 \mathrm{~S}$ rRNA sequencing and phylogenetic analysis. Based on the results, the bacterial strain showed 99\% similarity to Enterococcus faecium. The sequence was submitted to GenBank, NCBI and got accession number MH113816 and the GRD S1 was named as Enterococcus faecium GRD AA. Enterococci, particularly Enterococcus faecium and Enterococcus faecalis are usually in milk ${ }^{31}$ and are also omnipresent in the environments of animal and human gastrointestinal tracts and in traditional fermented foods. The genus Enterococcus comprises a large number of bacteria, in certain cases, it is suitable as starter culture or probiotics and also in some other cases familiar as spoilage or infectious microorganisms. ${ }^{32}$ Certain strains of Enterococci has useful role in wide range of fermented foods, including dairy and vegetable commodities, evidently via proteolysis, lipolysis, exopolysaccharide production and citrate breakdown. ${ }^{33,34}$ Such as other lactic acid bacteria, enterococci are able to secrete antimicrobial substance, which makes them likely useful for the control of foodborne illness caused by the bacteria. ${ }^{35}$

\section{Production and Purification of antilisterial bacteriocin ALC102}

Antilisterial bacteriocin production from Enterococcus faecium GRD AA was carried out in production medium (TGE+Tween 80 ), which aided maximum bacteriocin production. Extraction of crude antilisterial bacteriocin was done using Amberlite XAD-16 adsorption, which is a non-ionic 
macro reticular resin that absorbs and release ionic species through hydrophobic interactions. ${ }^{36}$ The antilisterial bacteriocin will selectively adhere to the amberlite resin which were added to the cell free buoyant. The bounded bacteriocin were eluted by column chromatography method and the amberlite fraction was evaporated to half

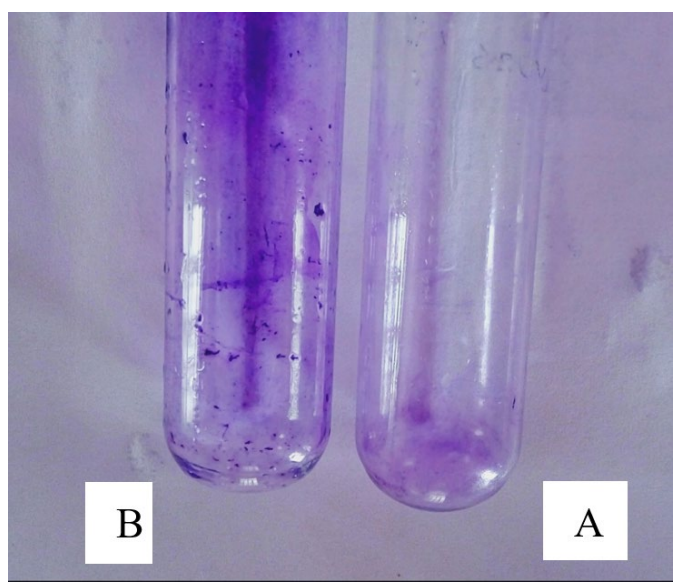

Fig. 1. The biofilm formation by Listeria monocytogenes MTCC657 by tube method, A- Control, B- Test strain with crystal violet staining indicates biofilm formation. the volume and stored in $4^{\circ} \mathrm{C}$ for further analysis. Numerous strains of enterococci produce not less than one bacteriocin, antimicrobial peptide that is synthesized ribosomally that are active against a various foodborne pathogens including Listeria spp. ${ }^{37}$ According to the classification by, ${ }^{38}$ most of the enterocins produced by enterococci are class II bacteriocins, explained as non-modified and thermo stable. This class of bacteriocin produced by enterococci includes pediocin like bacteriocins with a tough activity against Listeria spp. The bacteriocin production by Enterococcus spp. perhaps be a favorable trait in some conditions to enhance competitiveness of the producer strain to establish its habitat amid other microbial groups in antagonistic environment. ${ }^{39,40}$

\section{Biofilm formation studies}

Preliminary studies to find out the biofilm formation capacity of Listeria monocytogenes MTCC 657 were carried out by tube method and microtiter plate method.

\section{Tube method}

The tube method involves the adherence by Listeria monocytogenes MTCC 657 on the sides of test tube which was assessed visually. In this

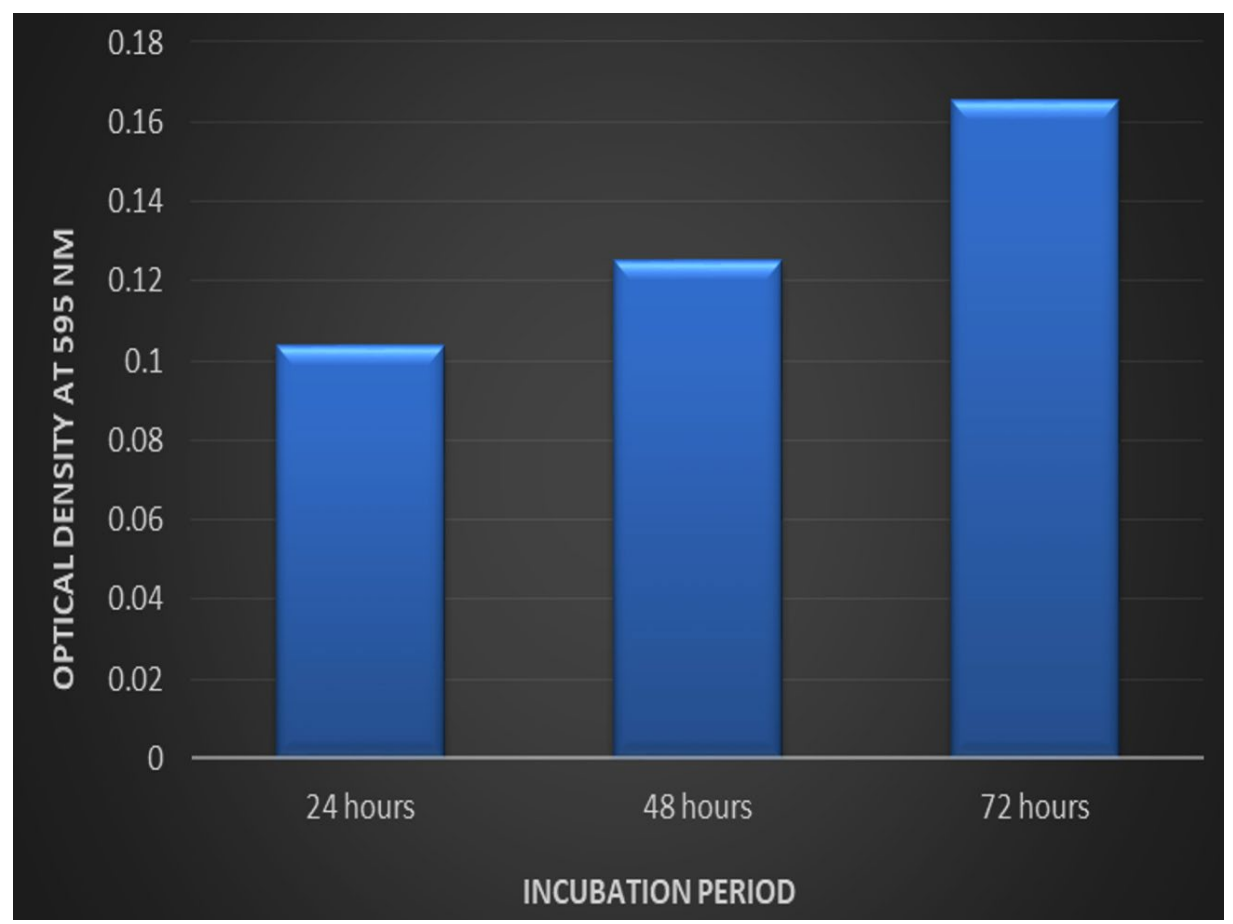

Fig. 2. Biofilm formation by Listeria monocytogenes MTCC 657 at different incubation period in crystal violet binding assay 
study, Listeria monocytogenes MTCC 657 showed positive results of biofilm formation after crystal violet staining (Fig. 1.) and this indicates that Listeria monocytogenes MTCC 657 is strong biofilm producer.

There are different strategies implied by microorganisms for biofilm production and to understand pathways. According ${ }^{41}$ report, scientists has reported that biofilm producing bacterial strains emit certain chemicals that protect them from sanitizers and antimicrobial agents. Tube method is one of the dependable quantitative analysis for biofilm formation. It is one of the primary screening method for detection of biofilm production by bacteria in laboratory level. ${ }^{26}$ Microtiter plate method: The biofilm formation ability of Listeria monocytogenes MTCC 657 by microtiter plate method was evaluated.

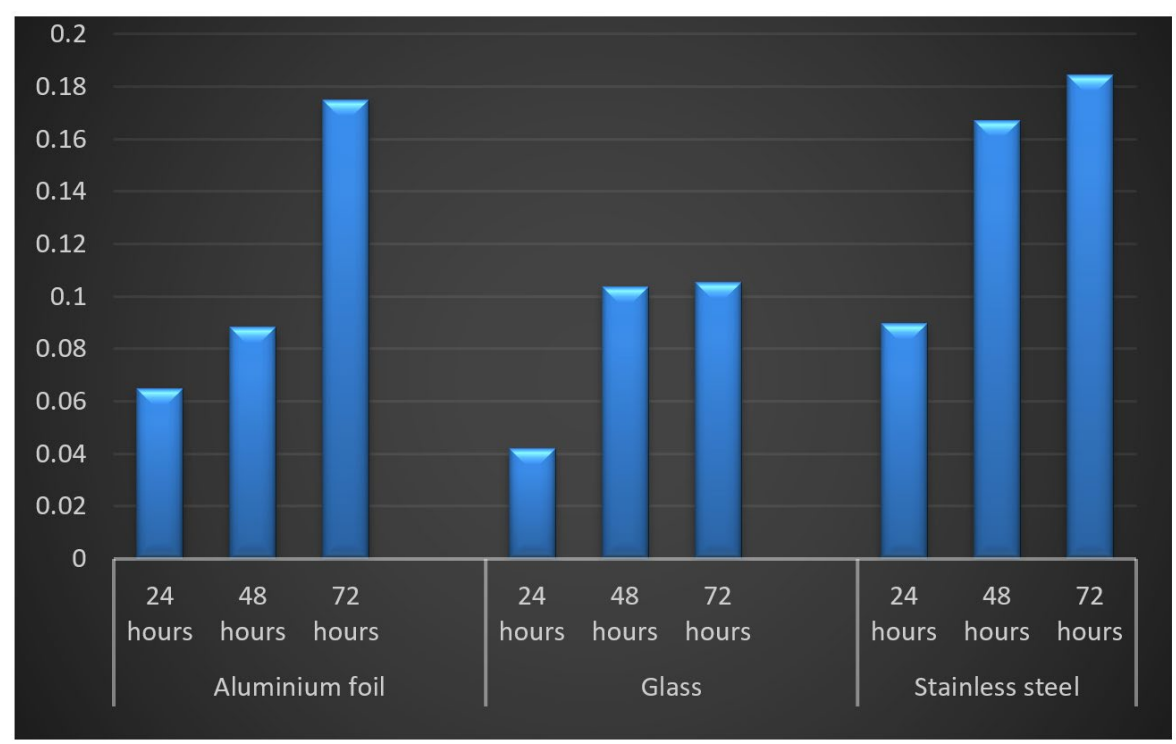

Fig. 3. Biofilm formation on by Listeria monocytogenes MTCC 657 on different substrates at different incubation periods.

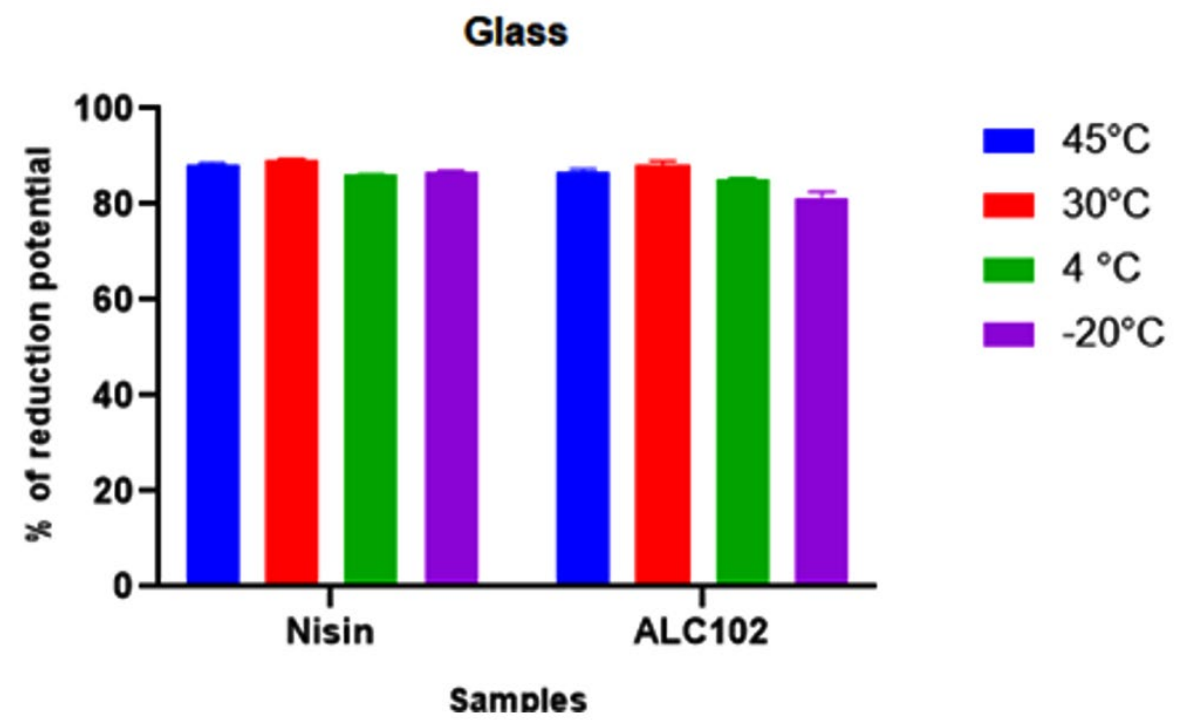

Fig. 4. Y-axis represents the reduction potential (\%) of L. monocytogenes MTCC 657 and X-axis represents the bacteriocins nisin and ALC102 on Glass substrate. 
Optical density of Listeria monocytogenes MTCC 657 biofilm grown at $24 \mathrm{~h}, 48 \mathrm{~h}$ and $72 \mathrm{~h}$ were observed spectrophotometrically at $595 \mathrm{~nm}$. From the results, Listeria monocytogenes MTCC 657 was able to form biofilm at $24 \mathrm{~h}$ itself. The OD ranged from 0.103 to 0.165 (Fig. 2.) after $72 \mathrm{~h}$. The biofilm production seems to be increasing as the incubation increases..$^{30}$ Biofilm formation is a complicated process which is influenced by factors such as time, temperature and growth medium. ${ }^{42}$ Biofilm formation on different substrates

Three abiotic surfaces glass, aluminum foil and stainless steel were selected for different incubation periods. The selection of substrates was

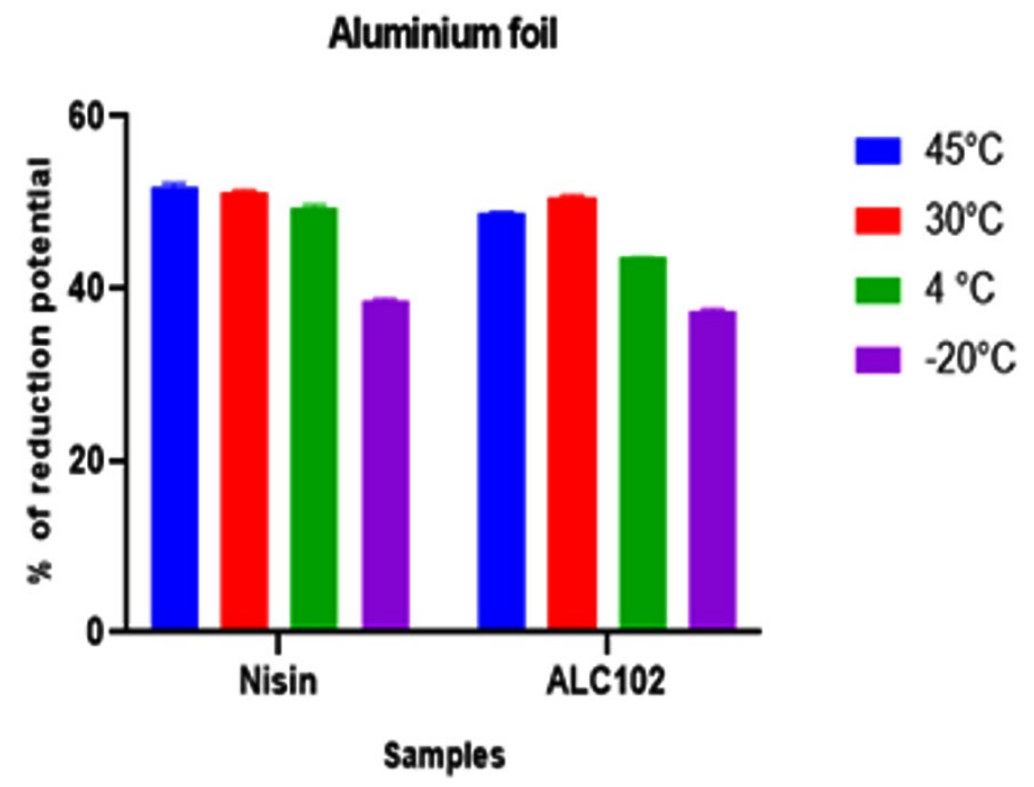

Fig. 5. Y-axis represents the reduction potential (\%) of L. monocytogenes MTCC 657 and X-axis represents the bacteriocins nisin and ALC102 aluminum foil substrate.

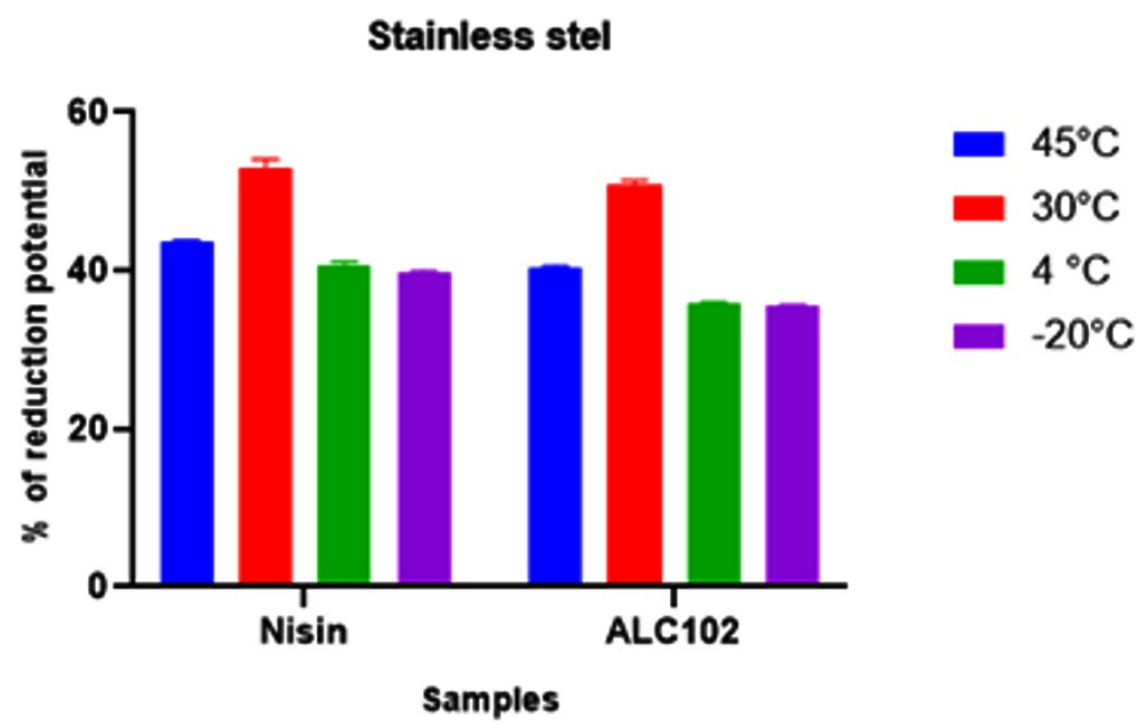

Fig. 6. Y-axis represents the reduction potential (\%) of L. monocytogenes MTCC 657 and X-axis represents the bacteriocins nisin and ALC102 stainless steel substrate 
Table 1. Susceptibility of Listeria monocytogenes MTCC 657 for Nisin and ALC102 at $45^{\circ} \mathrm{C}$

\begin{tabular}{|c|c|c|c|c|}
\hline \multirow{2}{*}{$\begin{array}{l}\text { Conc.of } \\
\text { bacteriocin } \\
\mu \mathrm{g} / \mathrm{ml}\end{array}$} & \multicolumn{2}{|c|}{ MIC } & \multicolumn{2}{|c|}{ MBEC } \\
\hline & Nisin & ALC102 & Nisin & ALC102 \\
\hline 1280 & $0.073 \pm 0.003$ & $0.070 \pm 0.001$ & $0.079 \pm 0.002$ & $0.068 \pm 0.001$ \\
\hline 640 & $0.075 \pm 0.003$ & $0.072 \pm 0.002 a$ & $0.082 \pm 0.001$ & $0.069 \pm 0.003$ \\
\hline 320 & $0.077 \pm 0001$ & $0075 \pm 0.004$ & $0.085 \pm 0.003$ & $0.070 \pm 0.001^{\mathrm{a}}$ \\
\hline 160 & $0.081 \pm 0.002$ & $0.076 \pm 0.009$ & $0.088 \pm 0.001$ & $0.072 \pm 0.001$ \\
\hline 80 & $0.084 \pm 0.002$ & $0.078 \pm 0.001 a$ & $0.092 \pm 0.002$ & $0.073 \pm 0.002$ \\
\hline 40 & $0.086 \pm 0.001$ & $0.079 \pm 0.002$ & $0.094 \pm 0.001$ & $0.074 \pm 0.001^{a}$ \\
\hline 20 & $0.089 \pm 0.002$ & $0.082 \pm 0.002$ & $0.095 \pm 0.003$ & $0.075 \pm 0.002^{\mathrm{a}}$ \\
\hline 10 & $0.091 \pm 0.001$ & $0.083 \pm 0.001$ & $0.097 \pm 0.001$ & $0.079 \pm 0.002$ \\
\hline
\end{tabular}

The given values are the optical density of $L$. monocytogenes MTCC 657 biofilm obtained by measuring the turbidity at $650 \mathrm{~nm}$ on Elisa plate reader and indicted as Mean \pm SD at significance $p<0.05$. ${ }^{a}$ - significant relationship between Nisin and ALC102.

Table 2. Susceptibility of Listeria monocytogenes MTCC 657 for Nisin and ALC102 at $30^{\circ} \mathrm{C}$

\begin{tabular}{|c|c|c|c|c|}
\hline \multirow{2}{*}{$\begin{array}{l}\text { Conc.of } \\
\text { bacteriocin } \\
\mu \mathrm{g} / \mathrm{ml}\end{array}$} & \multicolumn{2}{|c|}{ MIC } & \multicolumn{2}{|c|}{ MBEC } \\
\hline & Nisin & ALC102 & Nisin & ALC102 \\
\hline 1280 & $0.061 \pm 0.002$ & $0.066 \pm 0.001^{\mathrm{a}}$ & $0.057 \pm 0.002$ & $0.065 \pm 0.001$ \\
\hline 640 & $0.065 \pm 0.001$ & $0.067 \pm 0.002$ & $0.056 \pm 0.002$ & $0.067 \pm 0.002$ \\
\hline 320 & $0.066 \pm 0.002$ & $0.068 \pm 0.004^{a}$ & $0.059 \pm 0.001$ & $0.069 \pm 0.002$ \\
\hline 160 & $0.071 \pm 0.001$ & $0.069 \pm 0.002$ & $0.061 \pm 0.003$ & $0.071 \pm 0.004$ \\
\hline 80 & $0.073 \pm 0.001$ & $0.071 \pm 0.002$ & $0.065 \pm 0.002$ & $0.074 \pm 0.001^{a}$ \\
\hline 40 & $0.078 \pm 0.003$ & $0.072 \pm 0.001$ & $0.067 \pm 0.003$ & $0.075 \pm 0.001^{a}$ \\
\hline 20 & $0.081 \pm 0.001$ & $0.075 \pm 0.002^{\mathrm{a}}$ & $0.071 \pm 0.002$ & $0.078 \pm 0.002$ \\
\hline 10 & $0.082 \pm 0.002$ & $0.079 \pm 0.001^{a}$ & $0.072 \pm 0.001$ & $0.080 \pm 0.001$ \\
\hline
\end{tabular}

The given values are the optical density of $L$. monocytogenes MTCC 657 biofilm obtained by measuring the turbidity at $650 \mathrm{~nm}$ on Elisa plate reader and indicated as Mean \pm SD at significance $p<0.05$. ${ }^{a}$ - significant relationship between Nisin and ALC102.

Table 3. Susceptibility of Listeria monocytogenes MTCC 657 for Nisin and ALC102 at $4^{\circ} \mathrm{C}$

\begin{tabular}{|c|c|c|c|c|}
\hline \multirow{2}{*}{$\begin{array}{l}\text { Conc.of } \\
\text { bacteriocin } \\
\mu \mathrm{g} / \mathrm{ml}\end{array}$} & \multicolumn{2}{|c|}{ MIC } & \multicolumn{2}{|c|}{ MBEC } \\
\hline & Nisin & ALC102 & Nisin & ALC102 \\
\hline 1280 & $0.071 \pm 0.002$ & $0.060 \pm 0.001$ & $0.056 \pm 0.001$ & $0.062 \pm 0.001$ \\
\hline 640 & $0.076 \pm 0.002$ & $0.062 \pm 0.001$ & $0.058 \pm 0.001$ & $0.064 \pm 0.001$ \\
\hline 320 & $0.081 \pm 0.001$ & $0.065 \pm 0.002$ & $0.061 \pm 0.002$ & $0.065 \pm 0.002^{\mathrm{a}}$ \\
\hline 160 & $0.085 \pm 0.003$ & $0.071 \pm 0.001^{a}$ & $0.063 \pm 0.001$ & $0.069 \pm 0.001$ \\
\hline 80 & $0.089 \pm 0.002$ & $0.074 \pm 0.001^{a}$ & $0.067 \pm 0.003$ & $0.072 \pm 0.001$ \\
\hline 40 & $0.092 \pm 0.001$ & $0.079 \pm 0.001$ & $0.071 \pm 0.001$ & $0.074 \pm 0.001^{\mathrm{a}}$ \\
\hline 20 & $0.094 \pm 0.003$ & $0.082 \pm 0.002$ & $0.076 \pm 0.001$ & $0.077 \pm 0.001^{\mathrm{a}}$ \\
\hline 10 & $0.095 \pm 0.002$ & $0.086 \pm 0.002^{\mathrm{a}}$ & $0.079 \pm 0.002$ & $0.081 \pm 0.001^{a}$ \\
\hline
\end{tabular}

The given values are the optical density of $L$. monocytogenes MTCC 657 biofilm obtained by measuring the turbidity at $650 \mathrm{~nm}$ on Elisa plate reader and indicated as Mean \pm SD at significance $p<0.05$. ${ }^{a}$ - significant relationship between Nisin and ALC102 
Krishna et al. | J Pure Appl Microbiol | 16(1):481-493 | March 2022 | https://doi.org/10.22207/JPAM.16.1.46

Table 4. Susceptibility of Listeria monocytogenes MTCC 657 for Nisin and ALC102 at $-20^{\circ} \mathrm{C}$

\begin{tabular}{lccccc}
\hline \multirow{2}{*}{$\begin{array}{l}\text { Conc.of } \\
\text { bacteriocin } \\
\mu \mathrm{g} / \mathrm{ml}\end{array}$} & \multicolumn{2}{c}{ MIC } & & \multicolumn{2}{c}{ MBEC } \\
\cline { 2 - 3 } \cline { 5 - 6 } & Nisin & ALC102 & & Nisin & ALC102 \\
\hline 1280 & $0.053 \pm 0.001$ & $0.052 \pm 0.002$ & & $0.056 \pm 0.001$ & $0.065 \pm 0.001$ \\
640 & $0.055 \pm 0.003$ & $0.053 \pm 0.001$ & & $0.059 \pm 0.002$ & $0.061 \pm 0.003$ \\
320 & $0.061 \pm 0.002$ & $0.055 \pm 0.001$ & & $0.061 \pm 0.001$ & $0.064 \pm 0.001$ \\
160 & $0.063 \pm 0.001$ & $0.059 \pm 0.001$ & & $0.063 \pm 0.002$ & $0.065 \pm 0.001$ \\
80 & $0.069 \pm 0.002$ & $0.062 \pm 0.003$ & & $0.065 \pm 0.003$ & $0.067 \pm 0.002$ \\
40 & $0.071 \pm 0.002$ & $0.064 \pm 0.001$ & & $0.068 \pm 0.001$ & $0.071 \pm 0.003$ \\
20 & $0.076 \pm 0.003$ & $0.068 \pm 0.001$ & & $0.072 \pm 0.002$ & $0.072 \pm 0.001$ \\
10 & $0.081 \pm 0.002$ & $0.070 \pm 0.002$ & & $0.078 \pm 0.001$ & $0.076 \pm 0.001$
\end{tabular}

The given values are the optical density of $L$. monocytogenes MTCC 657 biofilm obtained by measuring the turbidity at $650 \mathrm{~nm}$ on Elisa plate reader and indicated as Mean \pm SD at significance $p<0.05 .{ }^{a}$ - significant relationship between Nisin and ALC102

based on their relevance in the food industry. For 24h, Listeria monocytogenes MTCC 657 formed strong biofilm on stainless steel (OD-0.185) followed by aluminum foil (OD-0.064) and glass (OD-0.042). Similar results were observed in $48 \mathrm{~h}$ and $72 \mathrm{~h}$. From the results, it is clear that Listeria monocytogenes MTCC 657 has higher ability to form biofilm on these abiotic substrates Krishna et al. ${ }^{30}$ The absorbance values of biofilm adherence of Listeria monocytogenes MTCC 657, stainless steel maintained higher biofilm formation than aluminum foil and glass (Fig. 3.).

The strong biofilm formation could be due to the surface hydrophobicity in stainless steel and other physciochemical properties compared to other surfaces. Cellular hydrophobicity is another physciochemical factor which may influence bacterial adhesion on surfaces. ${ }^{43}$ Biofilm formation by Listeria monocytogenes is affected not only by lineage and origin of the strain, but also by internal and external food factors. ${ }^{17}$

\section{Biofilm eradication studies on Listeria monocytogenes MTCC 657 \\ Microtiter plate method}

The objective of the study was to evaluate the biofilm forming ability of Listeria monocytogenes MTCC 657 on different abiotic substrates (glass, aluminum foil and stainless steel) at different temperatures $\left(45^{\circ} \mathrm{C}, 30^{\circ} \mathrm{C}, 4^{\circ} \mathrm{C}\right.$ and $-20^{\circ} \mathrm{C}$ ) and to assess the biofilm eradication potential of Nisin and antilisterial bacteriocin ALC102. All the experiments were performed in triplicates. From the results, ALC102 bacteriocin has almost similar activity when compared to commercially available bacteriocin Nisin. (Fig. 4. 5. And 6.)

From the results got from the study, the biofilm eradication potential of ALC102 and Nisin were found to be similar. Nisin was selected as standard bacteriocin in our study as it is a proven commercially available bacteriocin. Nisin coated food packaging materials have budding applications in the control of growth of various foodborne pathogens and also on the spores of Clostridium botulinum and Listeria monocytogenes. ${ }^{44}$

Nisin's inhibitory effect on biofilm produced by Oenococcus oeni on stainless steel surfaces and recorded the use of nisin also pediocin PD-1 and plantaricin 423 bacteriocins in the eradication of biofilms from the surfaces. ${ }^{24}$ In spite, not being accepted for economical use as a food additive, bacteriocins from Enterococcus spp. like enterocin, are consistently evaluated for preservation of food materials. Different bacteriocins are able to prevent the growth of foodborne pathogens via pre-forming mechanisms in the bacterial cytoplasmic membrane, which results in apoptosis. ${ }^{45,46}$

\section{Calgary Biofilm Device (CBD $\left.{ }^{\circledR}\right)$}

Based on the results, both the bacteriocins ALC102 and Nisin were found to be capable to eradicate the biofilm produed by Listeria monocytogenes MTCC 657 regardless of the temperatures. The results are depicted in the tables as follows (Table 1. 2., 3. and 4). 
From the results, it can be concluded that the Listeria monocytogenes MTCC 657 biofilm eradication potential of bacteriocin ALC102 is almost similar to that of Nisin. The starvation and cold stress enhances the biofilm formation, surface hydrophobicity and modify the membrane lipopeptides of Listeria monocytogenes. The evaluation of antibiofilm activities of antimicrobial agents is generally depends on intervention with quorum sensing, inhibition attachment, increase of dispersion and various experimental and promising alternatives such as the use of biofilm specific antibodies, bacteriophage precised treatments and the species specific control of biofilms. ${ }^{47}$, ${ }^{48}$ From the results, the biofilm eradication potential of antilisterial bacteriocin ALC102 was found to be a potential competitor commercial bacteriocin nisin and it is recommendable for use in the application food preservation and in food processing industry.

\section{CONCLUSION}

In this study, antilisterial bacteriocin production and biofilm eradication potential of Enterococcus faecium GRD AA isolated from milk sample were investigated in vitro. From 15 isolates, only one strain was found to be Gram positive, catalase negative and identified to be Enterococcus faecium (MH113816) by $16 \mathrm{~S}$ rRNA gene sequencing and found to be antagonistic to foodborne pathogen Listeria monocytogenes MTCC 657. In a parallel study conducted, the biofilm forming ability of Listeria monocytogenes MTCC 657 were assessed by tube method and CV binding assay and found that the strain to be a tough biofilm producer. And also biofilm formation on different abiotic substrates were also studied among which stainless steel had strong biofilm formation. The biofilm eradication potential of antilisterial bacteriocin ALC102 along with nisin (commercial bacteriocin) were assessed by MTP method and $\mathrm{CBD}^{\circledR}$ method. Both nisin and ALC102 showed similar activities despite of temperature and incubation period. From our results, we highly recommend the use of antilisterial bacteriocin ALC102 in the food industry as a food additive. However, the detailed study about the structure and characteristics of the bacteriocin is mandatory for further research.

\section{ACKNOWLEDGMENTS}

None.

\section{CONFLICT OF INTREST}

The authors declare that there is no conflict of interest.

\section{AUTHORS' CONTRIBUTION}

All authors listed have made a substantial, direct and intellectual contribution to the work, and approved it for publication.

\section{FUNDING}

None.

\section{DATA AVAILABILITY}

The datasets generated and analyzed during the current study are available from the corresponding author on reasonable request.

\section{ETHICS STATEMENT}

Not applicable.

\section{REFERNCES}

1. Donlan RM, Costerton JW. Biofilms: survival mechanisms of clinically relevant microorganisms. Clin Microbiol Rev. 2002;15(2):167-193. doi: 10.1128/ CMR.15.2.167-193.2002

2. Flemming HC, Neu TR, Wozniak DJ. The EPS matrix: the "house of biofilm cells". J Bacteriol. 2007;189(22):7945-7947. doi: 10.1128/JB.00858-07

3. Azeredo J, Azevedo NF, Briandet R, et al. Critical review on biofilm methods. Crit Rev Microbiol. 2017;43(3):313351. doi: 10.1080/1040841X.2016.1208146

4. Murray EGD, Webb RA, Swann MBR. A disease of rabbits characterised by a large mononuclear leucocytosis, caused by a hitherto undescribed bacillus Bacterium monocytogenes (n. sp.). The Journal of Pathology and Bacteriology. 1926;29(4):407-439. doi: 10.1002/path.1700290409

5. Schlech WF, Lavigne PM, Bortolussi RA, et al. Epidemic listeriosis-evidence for transmission by food. $N$ Eng J Med. 1983;308(4):203-206. doi: 10.1056/ NEJM198301273080407

6. de Noordhout CM, Devleesschauwer B, Angulo FJ, et al. The global burden of listeriosis: a systematic review and meta-analysis. Lancet Infect Dis. 2014;14(11):10731082. doi: 10.1016/S1473-3099(14)70870-9

7. McLauchlin J. Human listeriosis in Britain, 1967-85, a summary of 722 cases. 1. Listeriosis during pregnancy and in the newborn. Epidemiol Infect. 1990;104(2):181189. doi: $10.1017 /$ S0950268800059343

8. Buchanan TS, Lloyd DG, Manal K, Besier TF. Neuromusculoskeletal modeling: estimation of muscle forces and joint moments and movements from measurements of neural command. J Appl Biomech. 
2004;20(4):367-395. doi: 10.1123/jab.20.4.367

9. foodborne pathogen that knows how to survive. Int J Food Microbiol. 2007;113(1):1-15. doi: 10.1016/j. ijfoodmicro.2006.07.008

10. Carpentier B, Cerf O. Review--Persistence of Listeria monocytogenes in food industry equipment and premises. Int J Food Microbiol. 2011;145(1):1-8. doi: 10.1016/j.ijfoodmicro.2011.01.005

11. Chambel MJ, Castanheira F. They don't want to be temporaries: Similarities between temps and core workers. J Organ Behav. 2007;28(8):943-59. doi: 10.1002/job.471

12. Moretro $\mathrm{T}$, Langsrud S. Listeria monocytogenes: biofilm formation and persistence in food-processing environments. Biofilms. 2004;1(2):107-121. doi: 10.1017/S1479050504001322

13. Silva S, Teixeira P, Oliveira R, Azeredo J. Adhesion to and viability of Listeria monocytogenes on food contact surfaces. J Food Prot. 2008;71(7):1379-1385. doi: 10.4315/0362-028X-71.7.1379

14. Hall-Stoodley L, Costerton JW, Stoodley P. Bacterial biofilms: from the natural environment to infectious diseases. Nat Rev Microbiol. 2004;2(2):95-108. doi: 10.1038/nrmicro821

15. da Silva EP, De Martinis ECP. Current knowledge and perspectives on biofilm formation: the case of Listeria monocytogenes. Appl Microbiol Biotechnol. 2013;97(3):957-968. doi: 10.1007/s00253-012-4611-1

16. Poimenidou S, Belessi CA, Giaouris ED, Gounadaki AS, Nychas GJ, Skandamis PN. Listeria monocytogenes attachment to and detachment from stainless steel surfaces in a simulated dairy processing environment. Appl Environ Microbiol. 2009;75(22):7182-7188. doi: 10.1128/AEM.01359-09

17. Reis-Teixeira FBD, Alves VF, de Martinis ECP. Growth, viability and architecture of biofilms of Listeria monocytogenes formed on abiotic surfaces. Braz J Microbiol. 2017;48(3):587-591. doi: 10.1016/j. bjm.2017.01.004

18. Galie S, Garcia-Gutierrez C, Miguelez EM, Villar CJ, Lombo F. Biofilms in the Food Industry: Health Aspects and Control Methods. Front Microbiol. 2018;9:898. doi: 10.3389/fmicb.2018.00898

19. Javed A, Masud T, ul Ain Q, Imran M, Maqsood S. Enterocins of Enterococcus faecium, emerging natural food preservatives. Annals of Microbiology. 2011;61(4):699-708. doi: 10.1007/s13213-011-0223-8

20. Den-Berghe EV, De Winter T, De Vuyst L. Enterocin A production by Enterococcus faecium FAIR-E 406 is characterised by a temperature- and $\mathrm{pH}$ dependent switch-off mechanism when growth is limited due to nutrient depletion. Int J Food Microbiol. 2006;107(2):159-170. doi: 10.1016/j. ijfoodmicro.2005.08.027

21. Cocolin L, Foschino R, Comi G, Fortina MG. Description of the bacteriocins produced by two strains of Enterococcus faecium isolated from Italian goat milk. Food Microbiol. 2007;24(7-8):752-758. doi: 10.1016/j. fm.2007.03.001

22. Chen YS, Yanagida F, Srionnual S. Characteristics of bacteriocin-like inhibitory substances from dochi- isolated Enterococcus faecium D081821 and D081833. Lett App/ Microbiol. 2007;44(3):320-325. doi:10.1111/ j.1472-765X.2006.02058.x

23. Heuer H, Krsek M, Baker P, Smalla K, Wellington EM. Analysis of actinomycete communities by specific amplification of genes encoding 16S rRNA and gelelectrophoretic separation in denaturing gradients. Appl Environ Microbiol. 1997;63(8):3233-3241. doi: 10.1128/aem.63.8.3233-3241.1997

24. Mahdavi M, Jalali M, Kermanshahi RK. The effect of nisin on biofilm forming foodborne bacteria using microtiter plate method. Res Pharm Sci. 2007;2(2):113118.

25. Christensen BE, Tronnes HN, Vollan K, Smidsrod O, Bakke R. Biofilm removal by low concentrations of hydrogen peroxide. Biofouling. 1990;2(2):165-175. doi: 10.1080/08927019009378142

26. Lima JLDC, Alves LR, Paz JNPD, Rabelo MA, Maciel MAV, Morais MMC. Analysis of biofilm production by clinical isolates of Pseudomonas aeruginosa from patients with ventilator-associated pneumonia. Rev Bras Ter Intensiva. 2017;29(3):310-316.

27. Stepanovic $S$, Vukovic D, Hola V, et al. Quantification of biofilm in microtiter plates: overview of testing conditions and practical recommendations for assessment of biofilm production by staphylococci. APMIS. 2007;115(8):891-899. doi: 10.1111/j.16000463.2007.apm_630.x

28. Pawar DM, Rossman ML, Chen J. Role of curli fimbriae in mediating the cells of enterohaemorrhagic Escherichia coli to attach to abiotic surfaces. J Appl Microbiol. 2005;99(2):418-425. doi: 10.1111/j.13652672.2005.02499.x

29. Allan N, Omar A, Harding MW, Olson M. A rapid, high-throughput method for culturing, characterizing and biocide efficacy testing of both planktonic cells and biofilms. Science against microbial pathogens: communicating current research and technological advances. Edition: Microbiology Book Series ed: Formatex, Editors: Mendez-Vilas A. 2011:864-71. https://www.researchgate.net/ publication/263009481

30. Krishna AR. Effect of Bacteriocin of Paenibacillus Polymyxa on Biofilm Forming Listeria Monocytogenes MTCC 657. Biosc Biotech Res Comm. 2020;13(2):819828. doi: $10.21786 / \mathrm{bbrc} / 13.2 / 66$

31. Bhardwaj A, Gupta H, Kapila S, Kaur G, Vij S, Malik RK. Safety assessment and evaluation of probiotic potential of bacteriocinogenic Enterococcus faecium $\mathrm{KH} 24$ strain under in vitro and in vivo conditions. Int J Food Microbiol. 2010;141(3):156-164. doi: 10.1016/j. ijfoodmicro.2010.05.001

32. Moreno MRF, Sarantinopoulos P, Tsakalidou E, De Vuyst $\mathrm{L}$. The role and application of enterococci in food and health. Int J Food Microbiol. 2006;106(1):1-24. doi: 10.1016/j.ijfoodmicro.2005.06.026

33. Giraffa G. Functionality of enterococci in dairy products. Int J Food Microbiol. 2003;88(2-3):215-222. doi: 10.1016/S0168-1605(03)00183-1

34. M'hir S, Minervini F, Di Cagno R, Chammem N, Hamdi $M$. Technological, functional and safety aspects of enterococci in fermented vegetable products: a 
mini-review. Ann Microbiol. 2012;62(2):469-481. doi: 10.1007/s13213-011-0363-x

35. Saris PE. Biopreservation by lactic acid bacteria. Dairy Microbiology and Biochemistry: Recent Developments. 2014:86. doi: 10.1201/b17297-5

36. Zeng Z, Guo XP, Li B, et al. Characterization of selfgenerated variants in Pseudoalteromonas lipolytica biofilm with increased antifouling activities. Appl Microbiol Biotechnol. 2015;99(23):10127-10139. doi: 10.1007/s00253-015-6865-x

37. Ness IF, Diep DB, Ike Y. Enterococcal Bacteriocins and Antimicrobial Proteins that Contribute to Niche Control. In: Gilmore MS, Clewell DB, Ike Y, Shankar N, eds. Enterococci: From Commensals to Leading Causes of Drug Resistant Infection. Boston: Massachusetts Eye and Ear Infirmary; February 16, 2014. https:// europepmc.org/article/NBK/nbk190428

38. Cotter PD, Ross RP, Hill C. Bacteriocins - a viable alternative to antibiotics? Nat Rev Microbiol. 2013;11(2):95-105. doi: 10.1038/nrmicro2937

39. Dobson A, Cotter PD, Ross RP, Hill C. Bacteriocin production: a probiotic trait? Appl Environ Microbiol. 2012;78(1):1-6. doi: 10.1128/AEM.05576-11

40. Vimont A, Fernandez B, Hammami R, Ababsa A, Daba $\mathrm{H}$, Fliss I. Bacteriocin-Producing Enterococcus faecium LCW 44: A High Potential Probiotic Candidate from Raw Camel Milk. Front Microbiol. 2017;8:865. doi: 10.3389/ fmicb.2017.00865

41. Saitou K, Furuhata K, Kawakami Y, Fukuyama M. Biofilm formation abilities and disinfectantresistance of Pseudomonas aeruginosa isolated from cockroaches captured in hospitals. Biocontrol science. 2009;14(2):65-68. doi: 10.4265/bio.14.65
42. Bjarnsholt T. The role of bacterial biofilms in chronic infections. APMIS Suppl. 2013;(136):1-58. doi: 10.1111/apm.12099

43. Chang Y, Gu W, McLandsborough L. Low concentration of ethylenediaminetetraacetic acid (EDTA) affects biofilm formation of Listeria monocytogenes by inhibiting its initial adherence. Food Microbiol. 2012;29(1):10-17. doi: 10.1016/j.fm.2011.07.009

44. Budde BB, Jakobsen M. Real-time measurements of the interaction between single cells of Listeria monocytogenes and nisin on a solid surface. Appl Environ Microbiol. 2000;66(8):3586-3591. doi: 10.1128/AEM.66.8.3586-3591.2000

45. Khan H, Flint S, Yu PL. Enterocins in food preservation. Int J Food Microbiol. 2010;141(1-2):1-0. doi: 10.1016/j. ijfoodmicro.2010.03.005

46. Camargo AC, Todorov SD, Chihib NE, Drider D, Nero LA. Lactic acid bacteria (LAB) and their bacteriocins as alternative biotechnological tools to control Listeria monocytogenes biofilms in food processing facilities. Molecular Biotechnology. 2018;60(9):712-726. doi: 10.1007/s12033-018-0108-1

47. Chen YP, Zhang P, Guo JS, Fang F, Gao X, Li C. Functional groups characteristics of EPS in biofilm growing on different carriers. Chemosphere. 2013;92(6):633-638. doi: 10.1016/j.chemosphere.2013.01.059

48. Slama RB, Kouidhi B, Zmantar T, Chaieb K, Bakhrouf A. Anti-listerial and anti-biofilm activities of potential Probiotic $L$ actobacillus strains isolated from $T$ unisian traditional fermented food. Journal of Food Safety. 2013;33(1):8-16. doi: 10.1111/jfs.12017 